\title{
2012 Dewey Lecture: Making Meaning Together Beyond Theory and Practice
}

\author{
Jim Garrison
}

\section{ABSTRACT}

Educators frequently fret over how to bridge the gap between theory and practice. In an important sense, it is a false problem. Theory is simply the thoughtful, reflective phase of good practice. We will approach Dewey's philosophy as one of continuous creation and re-creation or even more precisely, social co-creation, that requires making meaning, knowledge, and value together. We will look at each one of these three in some detail along with the ways they transact with one another. Fundamentally, we can only distinguish them for some purposes, but never fully separate them. Everywhere we look, we will see we cannot entirely pull theory and practice apart. Therefore, the paper will conclude that if we unify theory with practice, we may use the same paradigm for the intelligent production of meaning, knowing, and valuing, thereby obviating the functional independencies among them.

The reason the title of my paper is not Making Meaning Together Bridging Theory and Practice is that there is nothing to bridge. Theory and practice are simply subfunctions within the larger function of making meaning, knowledge, and value in our lives, although few thinkers have ever conceived it as such. The philosophy of John Dewey is a striking exception. Theory and practice unite within his account of production, or if you prefer, his account of construction and reconstruction. It indicates a constructivism far beyond anything found in the contemporary educational conversation. In "Construction and Criticism," Dewey writes, "I have used the word construction rather than creation because it seems less pretentious. But what I mean by it is the creative mind, the mind that is genuinely productive in its operations." It is not too much to call Dewey's philosophy one of continuous creation and re-creation, or even more precisely, social co-creation. We make meaning, knowledge, and value together.

We begin with a discussion of the role of theory before turning to practice and production in that order. Admittedly, it is something of a disjointed mechanical treatment, since the proper relation of theory, practice, and production constitutes a mutually interdependent functional relationship.

Significantly, the word theory derives from the classical Greek theoria, meaning "viewing, speculation, contemplation, the contemplative life."2 It is associated 
with theoros, meaning a spectator at a game. The Greeks assumed a dualistic separation between two modes of being, one lower and the other higher. The higher realm was comprised of pure, perfect, and immutable forms or essences knowable with absolute certainty, but only by means of pure speculative thought. In contrast, there was the empirical realm of nature comprised of contingent, mutable, and uncertain events about which we may only make crude trial and error conjectures. To preserve its purity, theoria must operate apart from experience, thereby making it necessary to detach reason from the corporeal body that is not only itself a corrupted thing of nature, but also the source of distorting passions. ${ }^{3}$ Early in his career, Dewey called such putative a priori pure thinking "apart thought" because it supposedly existed apart from anything empirical. ${ }^{4}$

To preserve pure thought it was also necessary to disconnect it from practice or production. Detached from the world, the spectator stance of thinking and knowing yielded the mind versus body, subject versus object, and knower versus known dualisms. In the history of western thought, pure speculative reason continued to completely sever itself from empirical investigation until the emergence of scientific inquiry, with its emphasis upon experiential practice in producing knowledge. For Dewey, the scientific method is continuous with intelligent method however unrefined. If we think of experience and experiment in the etymological sense of "to make a trial, proof, or a test," it is an extension of what good practitioners have always done anyway.

Theoria seeks episteme or indubitably certain truth, thereby yielding what Dewey calls the quest for certainty that still dominates western thought. Drawing on the etymology of the word, Dewey calls such an understanding of theory the spectator view. He contrasts it with his own Darwinian participatory stance, which assumes we construct our thoughts from the same contingent ever-evolving events of existence upon which we cogitate. By contrast, it is the task of pure speculative reason to position the knower for a perfectly clear and distinct view of the spectacle of absolute, fixed, and final essences. Dewey denies the very idea of nous and the possibility of immediate indubitable noetic intuitions of truth. ${ }^{5}$ For him, all thinking is dianoia; that is, a discursive mediated trace of empirical inferences and logical implications, which is not to deny the existence of immediate anoetic intuitions.

What theory contributes to practice and production is intelligence, which is why we must find a way to preserve it. However, theory cannot make its contribution by remaining pure speculation detached from worldly doing and making. We may reconnect intelligence to the world by repositioning it within human experience and then radically reconstructing it. Once we do so, we will realize that "that mode of practice which is called theorizing emancipates experience." ${ }^{\prime 6}$ Let us look at how Dewey integrates theory into the messy and contingent empirical world of practice.

According to Dewey, "the great vice of philosophy" is intellectualism. " This vice is at least as serious as dualism. Here is what he means by it: 
By "intellectualism" as an indictment is meant the theory that all experiencing is a mode of knowing, and that all subject-matter, all nature, is, in principle, to be reduced and transformed till it is defined in terms identical with the characteristics presented by refined objects of science as such. The assumption of "intellectualism" goes contrary to the facts of what is primarily experienced. For things are objects to be treated, used, acted upon and with, enjoyed and endured, even more than things to be known. They are things had before they are things cognized. ${ }^{8}$

We cannot think about existence until we have first experienced it. Primitively, experience is what happens to a sentient creature in its reciprocally trans-forming trans-actions with its natural environment, including the human created world of language and institutions we call culture. Dewey further indicates:

When intellectual experience and its material are taken to be primary, the cord that binds experience and nature is cut. That the physiological organism with its structures, whether in man or in the lower animals, is concerned with making adaptations and uses of material in the interest of maintenance of the life-process, cannot be denied. . . Hence, unless there is breach of historic and natural continuity, cognitive experience must originate within that of a non-cognitive sort. ${ }^{9}$

We bear many relations to existence, including joy, despair, horror, reverence, amusement, fear, confusion, and hope. Such experiences, inarticulate in themselves, give meaning, knowledge, and value their context. We carry out artistic practices that produce meaning, knowledge, and value to improve or at least ameliorate our noncognitive relationships with the world. We may also take immediate consummatory aesthetic delight in what we have made even as we continue to appreciate their mediating properties.

Let us now turn to Dewey's reconstruction of theoria. The following passage comments on pure reason as it has come down to us across the millennia:

Reasonableness or rationality has, however, been hypostatized. One of the oldest and most enduring traditions in logical theory has converted rationality into a faculty which, when it is actualized in perception of first truths, was called reason and later, Intellectus Purus. The idea of reason as the power which intuitively apprehends a priori ultimate first principles persists. ${ }^{10}$

For Dewey, all reasoning is practical means-ends reasoning carried out for the consequences it helps produce. That is why he writes: "Rationality as an abstract conception is precisely the generalized idea of the means-consequence relation as such." ${ }^{11}$ Dewey radically reconstructs theoria in terms of practical reasoning.

The result of Dewey's reconstruction is a new organum, a new tool of intelligence, newer still than the novum organum Francis Bacon proposed to overcome 
Aristotelian logic. Regrettably, many commentators confuse Dewey's instrumentalism with that of Aristotle and Bacon. The confusion extends to his understanding of science. While Dewey denies theoria's traditional status as pure intellect, he does preserve its function by reconstructing it in terms of ideas operating inside practical means-ends reasoning. Falsifiable nonexistential ideas established by prior inquiry, along with ideas in the guise of provisional hypotheses, guide inquiry. All inquiry is theory-laden. We may say the same for the role of ideal ends-in-view. All inquiry is also value-laden.

Let us pause to recall some of the frequently overlooked characteristics of Dewey's theory of inquiry. Inquiry always begins with some existential problematic situation; we do not begin with a cognitive problem. Dewey mentions that it "is a familiar and significant saying that a problem well put is half-solved. To find out what the problem and problems are which a problematic situation presents to be inquired into, is to be well along in inquiry." 12 The situation is problematic because it disrupts our functional coordination, thereby giving rise to needs and desires for something that will restore functioning. ${ }^{13}$ The task of inquiry is to re-coordinate the situation. Proposed nonexistential ideal ends-in-view provide the tentative, hence revisable, aim, goal, or value of the inquiry. The coordination of actual existential means and actual existential ends constitutes the aesthetic form of the existential situation that is the end or consequence of inquiry. ${ }^{14}$

Here is Dewey's definition of inquiry: "Inquiry is the controlled or directed transformation of an indeterminate situation into one that is so determinate in its constituent distinctions and relations as to convert the elements of the original situation into a unified whole." 15 The means constitute the existential end of inquiry, for without the means the end would not exist. Likewise, there are no means until we secure the end.

What may most surprise many is how important aesthetics is to the forgoing reconstruction. However, once we recall that theory and practice unite within Dewey's account of production, the surprise dissipates. We may start with Dewey's statement about those most abstract of cognitive things - ideas: "The idea is, in short, art and a work of art. As a work of art, it directly liberates subsequent action and makes it more fruitful in a creation of more meanings and more perceptions."16 "We cannot grasp any idea," he writes, "until we have felt and sensed it, as much so as if it were an odor or a color." 17 In a chapter in Experience and Nature titled "Experience, Nature and Art," Dewey insists that we must understand the importance of "putting art and creation first." 18 For those who can:

It would then be seen that science is an art, that art is practice, and that the only distinction worth drawing is not between practice and theory, but between those modes of practice that are not intelligent, not inherently and immediately enjoyable, and those which are full of enjoyed meanings. ${ }^{19}$ 
As indicated earlier, theory renders production intelligent. However, once fully integrated into creative production, practice tests and refines theory. The same holds for reason and intelligence themselves; they too are alterable according to the trials and refinements of practical experience. It is a virtuous circle.

Once we put art first and completely integrate theory into practice for the artistic purposes of intelligently producing and aesthetically appreciating meaning and value, many things become perspicuous. For instance:

When this perception dawns, it will be a commonplace that art-the mode of activity that is charged with meanings capable of immediately enjoyed possession-is the complete culmination of nature, and that "science" is properly a handmaiden that conducts natural events to this happy issue. Thus would disappear the separations that trouble present thinking: division of everything into nature and experience, of experience into practice and theory, art and science, of art into ... menial and free. ${ }^{20}$

We will return to discuss the division of menial versus free art. Here, however, it might be helpful to our subsequent discussion of Dewey's reconstruction of theoria and the recreation of practical reason to say more about the collapse of the art versus science dualism.

If there is any one error that is the primary source of misreading Dewey, it is confusing his theory of inquiry and science with the entirety of his philosophy. The error commonly confounds itself by confusing his theory and value-laden philosophy of science with scientism. For Dewey, "Scientific thought is . . in its turn, a specialized form of art." ${ }^{21}$ It is the art of producing well-warranted assertions. Now we may understand why "science itself is but a central art auxiliary to the generation and utilization of other arts." 22 Dewey declares that in "concrete operation, education is an art. ... If there were an opposition between science and art, I should be compelled to side with those who assert that education is an art. But there is no opposition, although there is a distinction." ${ }^{23}$ The distinction is simply that the specialized art of science confines itself to producing warranted assertions useful to other arts, such as teaching.

Let us return to Dewey's reconstruction of theoria and practical reasoning with the following quotation:

To be a man [sic] is to be thinking desire; and the agreement of desires is not in oneness of intellectual conclusion, but in the sympathies of passion and the concords of action:- and yet significant union in affection and behavior may depend upon a consensus in thought that is secured only by discrimination and comparison. ${ }^{24}$

This passage echoes the Nichomachean Ethics, where practical, not pure, reason rules supreme even for Aristotle. Desire has been a constituent part of practical reasoning since antiquity. Consider the following diagram: 


\begin{tabular}{|c|c|}
\hline \multirow{4}{*}{$\begin{array}{l}\text { Desire } \\
\text { Deliberation }\end{array}$} & I desire $\mathrm{V}$. \\
\hline & $\mathrm{U}$ is the means to $\mathrm{V}$. \\
\hline & $\mathrm{T}$ is the means to $\mathrm{U}$. \\
\hline & $\mathrm{N}$ is the means to $\mathrm{T}$. \\
\hline Perception & $\mathrm{N}$ is something I can do here and now. \\
\hline Choice & I choose $\mathrm{N}$. \\
\hline Action & I do N. \\
\hline
\end{tabular}

Here "I" is a person, "V" is a value, and $\mathrm{U}$ through $\mathrm{N}$ are means involving action. Note the initiating role of desire, along with the place of perception, in the conclusion. Given this course of reasoning, one ought to choose the possibility $\mathrm{N}$ and act on it. The ought here has moral force; it serves as a norm for judging the value of the choice. In his essay "Moral Theory and Practice," Dewey comments that "limiting the question as best I can, I should say (first) that the 'ought' always rises from and falls back into the 'is,' and (secondly) that the 'ought' is itself an 'is,'-the 'is' of action." ${ }^{25}$ For Dewey, the is of intelligent action involves reconstructing theoria and integrating it into his reconstructed theory of practical means-ends reasoning within his larger theory of inquiry. We will return to Dewey's unique understanding of the role of inquiry in transforming an is into an ought when we take up the creation of values.

Intelligent practice requires more than the abstract universal principles of pure logic or even what works according to the latest scientific research. Applying universal principles alone cannot realize the unique purposes of practical reasoning. If it did, how would we know which one to apply in particular, unique, and one-time-only teaching contexts? We would need more principles, but then how do we know when to apply these? We would need still more principles and so on forever. We have started a vicious infinite regress. It is precisely this kind of regress that led the first authority on practical reasoning, Aristotle, to conclude over 2300 years ago that "these are matters of perception. If we are to be always deliberating, we shall have to go on to infinity." ${ }^{26}$ The intuitive discernment rests with the perception of something had before it is fully cognized. At such moments, aesthetic sensitivity contributes to intelligent thought and action. Dewey recovers Aristotle's wisdom about practical reasoning even as he rejects the very idea of pure rationality. In Qualitative Thought, Dewey states that "intuition precedes conception and goes deeper." ${ }^{27}$ Notice that here anoetic intuition precedes conception, but as we have seen, it also concludes a course of reasoning. Thus, it is often as important to be somebody, a competent practitioner, than it is to know the rules of what works or be able to reason well.

We must not cut thought, reason, or, Dewey's much preferred word, intelligence off from our living involvements, needs, desires, interests, perceptions, cares, and concerns, which set the context of practice. There is also an important role for imagination and emotions other than desire. He declares: 
Deliberation is a dramatic rehearsal (in imagination) of various competing possible lines of action. It starts from the blocking of efficient overt action.... Deliberation is an experiment in finding out what the various lines of possible action are really like. It is an experiment in making various combinations of selected elements of habits and impulses, to see what the resultant action would be like if it were entered upon. But the trial is in imagination, not in overt fact. The experiment is carried on by tentative rehearsals in thought which do not affect physical facts outside the body.... An act tried out in imagination is not final or fatal. It is retrievable. ${ }^{28}$

Notice the role of embodied impulses and habits along with imagination in deliberation. We will come back to the role of experiment later. Besides the emphasis on creative imagination in inquiry, Dewey invokes embodied innate impulses as well as acquired habits. Unlike putatively pure reason, practical means-ends reasoning is embodied and impassioned. ${ }^{29}$

Desire is constitutive of deliberation, but all emotions may potentially enter into the process. Consider:

The conclusion is not that the emotional, passionate phase of action can be or should be eliminated in behalf of a bloodless reason. More "passions," not fewer, is the answer. To check the influence of hate there must be sympathy, while to rationalize sympathy there are needed emotions of curiosity, caution, respect for the freedom of others-dispositions which evoke objects which balance those called up by sympathy. ${ }^{30}$

To preserve itself pure reason must not commune with bodily fluids. What Dewey says about rational consciousness in philosophical idealism holds for all such disembodied dreams:

So, one asks, what is to become of idealism at large, of the wholesale unspecifiable determination of "reality" by or in consciousness, if . . . beings with bowels and brains, are found to exercise influence upon the character and existence of reals? ${ }^{31}$

Pure reason shuns practice least it acknowledge its animal relations with the world. It cannot make love. It can neither produce nor reproduce. It creates nothing at all unless it is confusion.

The following passage helps us see that not only complex passions, but also innate animal impulse, are involved in scientific method:

"Reason" as a noun signifies the happy cooperation of a multitude of dispositions, such as sympathy, curiosity, exploration, experimentation, frankness, pursuit. ... The elaborate systems of science are born not of reason but of impulses at first slight and flickering; impulses to handle, move about, to hunt, to uncover, to mix things separated and divide things combined, to talk and to listen.... Reason, the rational attitude, 


\section{Jim GARRISON}

is the resulting disposition, not a ready-made antecedent which can be invoked at will and set into movement. ${ }^{32}$

Notice the phrase, "the rational attitude, is the resulting disposition, not readymade" (op. cit.). Reason itself is among the emergent ever-evolving products of practice initiated by innate impulse (i.e., first nature), but rendered more or less intelligent by acquired habitual dispositions (i.e., second nature).

Dewey's reconstruction of theoria has social and political aspects that help identify the source of the theory and practice dualism:

The actual conditions of life in Greece ... set up a sharp division between doing and knowing, which was generalized into a complete separation of theory and "practice." It reflected, at the time, the economic organization in which "useful" work was done for the most part by slaves, leaving free men relieved from labor and "free" on that account. That such a state of affairs is also pre-democratic is clear. ${ }^{33}$

This pre-democratic social class division remains to haunt teachers whose tasks many consider menial rather than free.

Dewey decries what he calls "the segregations of educational values," of which that between the high culture of liberal studies and the utility of practical vocational education are "probably the most fundamental." ${ }^{34} \mathrm{He}$ declares:

While the distinction is often thought to be intrinsic and absolute, it is really historical and social. It originated, so far as conscious formulation is concerned, in Greece, and was based upon the fact that the truly human life was lived only by a few who subsisted upon the results of the labor of others. This fact affected the psychological doctrine of the relation of intelligence and desire, theory and practice. It was embodied in a political theory of a permanent division of human beings into those capable of a life of reason and hence having their own ends, and those capable only of desire and work, and needing to have their ends provided by others. ${ }^{35}$

What he says about liberal education and vocational education readily extends to the vocation of teaching. Too often, it is assumed that teachers engage in pedagogical practice while others capable of the life of reason, such as government bureaucrats, university professors, and educational researchers provide the teacher with the ethical and pedagogical ends or goods of their practice along with the means for achieving them promulgated by government "what works" websites. ${ }^{36}$ In Experience and Education, Dewey remarks:

Plato once defined a slave as the person who executes the purposes of another.... There is, I think, no point in the philosophy of progressive education which is sounder than its emphasis upon the importance of the participation of the learner in the formation of the purposes which direct his activities in the learning process. ${ }^{37}$ 
Sadly, we may say today of teachers what Dewey says of students.

Action, or more exactly the functional coordination of action, lies at the core of the very idea of pragmatism. After all in classical Greek pragma means "deed, act, concrete expression of praxis." 38 Practice derives from the Greek praxis, meaning "doing, transaction." ${ }^{39}$ For Aristotle, when praxis follows from deliberate choice, we may judge it moral or immoral. According to Peters, the Greeks largely confined the scope of practice to "ethics and politics, which have as their object the good that is aimed at by action. ${ }^{340}$ Greek aristocrats conceived politics as a free leisure activity that at least approached pure theoretical contemplation. The rest of what we would today call practice was left to the artisans who cultivated practical reason for the sake of creative production. Beneath the artisans in Greek society were the slaves engaged in ponos, meaning hard labor involving stress and suffering. They took the entirety of their means and ends from others. ${ }^{41}$ Traditionally, "as livelihood and leisure are opposed," Dewey remarks, "so are theory and practice, intelligence and execution, knowledge and activity." ${ }^{\prime 2}$

As Larry Hickman, the director of the Center for Dewey Studies, points out, "the activities of praxis included for the Greeks neither theoria nor the productive activities of the craftsman."43 Let us start with how Dewey connects theory to practice. We have seen how he reconstructed the character of theoria, but we need one more thing before we can understand how he integrates it into practice. Earlier we remarked that the ancient Greeks had a theory of experience, but they confined it to the lower, contingent, and changeable realm of existence completely apart from the higher realm of absolute being accessible only by pure speculative contemplation. ${ }^{44}$ Dewey thought it took a revolution, the scientific revolution, to unite theory and practice:

The division of the world into two kinds of Being, one superior, accessible only to reason and ideal in nature, the other inferior, material, changeable, empirical, accessible to sense-observation, turns inevitably into the idea that knowledge is contemplative in nature. It assumes a contrast between theory and practice which was all to the disadvantage of the latter. But in the actual course of the development of science, a tremendous change has come about. When the practice of knowledge ceased to be dialectical and became experimental, knowing became preoccupied with changes and the test of knowledge became the ability to bring about certain changes. Knowing, for the experimental sciences, means a certain kind of intelligently conducted doing; it ceases to be contemplative and becomes in a true sense practical. ${ }^{45}$

Stated somewhat differently:

The experimental method of scientific inquiry broke down the wall that had been erected between theory and practice. Knowing was not Theoria, 


\section{Jim GARRISON}

the contemplation of pure and complete Being, free from even the slightest trace of "practical" activity. Knowing involved some kind of doing and making. It turned away from immutability toward process, change. ${ }^{46}$

Systematic experimentation is a practical activity. It is precisely what was lacking in ancient Greek science. Although they respected experience, they took it "as is," as Dewey states, and "made no attempt to modify it radically before undertaking thinking and theorizing about it." ${ }^{37}$ Knowing involves systematically transforming experience, not taking it as given.

Experimental action unifies theory and practice such that we may artfully use theoretical ideas as a mode of practice, thereby emancipating experience:

Since the root of the traditional conception of philosophy is the separation that has been made between knowledge and action, between theory and practice, it is to the problem of this separation that we are to give attention. Our main attempt will be to show how the actual procedures of knowledge, interpreted after the pattern formed by experimental inquiry, cancel the isolation of knowledge from overt action. ${ }^{48}$

Galileo did not go down from Florence to the armory in Padua only to tell the artisans their business, he also went to learn his. Government and university based researchers and theorists of teaching should have a similar attitude.

Let us now turn to the unity of theory and practice in production. Techne is the skilled knowledge of poiesis, that is, making, creating, or calling into existence as Diotima teaches Socrates in the Symposium (205b). Hickman reminds us that, "techne was for the Greeks a pro-duction, a leading toward, and a con-struction, a drawing together, of various parts and pieces in order to make something novel." ${ }^{49}$ Dewey remarks, "the reproduction of the order of natural changes and the perception of that order were at first close together, so close that no distinction existed between art and science. They were both called techne." ${ }^{50} \mathrm{He}$ also asserts, "art denotes a process of doing or making. This is as true of fine as of technological art."

The unity of theoria and praxis in techne takes us to the heart of pragmatism. Consider:

There is a contemporary philosophic movement, popularly known as pragmatism, which, discontented with the current separation of theory and practise [sic], knowledge and action, regards thought and the beliefs which proceed from it as themselves modes of action and strives to envisage them in their directive office in conduct. ... It marks a return to the idea of philosophy which prevailed when reflective thought was young and lusty, eager to engage in combat in the public arena, instead of living a sheltered and protected life. In those days science and philosophy had not parted ways because neither of them was cut loose from the arts. One word designated both science and art: techne. ${ }^{52}$ 
Pragmatism reconstructs reason as the intelligent phase of the production of meaning, knowledge, and value. Pragmatism is not for the leisure class; its experimentalism means we cannot do everything from our study. We might need to do action research to enhance our pedagogical creativity or engage in politics to improve educational policy.

We now want to take up the unity of theory and practice in production. First, though, we need to identify another error that rivals dualism and intellectualism. Dewey thought meaning, knowledge, and value were all products of our creative activity. We must distinguish between the raw existence of meaningless events and qualities from the essences we create by means of our participation in them. "Essence is never existence," as Dewey expresses it, "and yet it is the essence, the distilled import, of existence." ${ }^{53}$ It is rather like distinguishing between existential grapes on the vine and the essence of the grapes for human purposes-wine. ${ }^{54}$

Dewey uses the phrase "the philosophic fallacy" to designate the crucial error of converting "eventual functions into antecedent existence," whether "performed in behalf of mathematical subsistences, esthetic essences, the purely physical order of nature, or God." ${ }^{55}$ It is the last mentioned that perhaps accounts for the marginalization of Deweyan philosophy. Norms and values, including the summum bonum, whatever you may take that to be, are all contingent constructions. Hence, they are subject to deconstruction, reconstruction, and outright destruction. There are no absolute ends in themselves anywhere in Dewey's philosophy. Let us now take up the making of meaning followed by the objects of knowledge and concluding with the creation of value.

What do teachers produce; better by far, what do they create? The Deweyan replay is "body-minds" capable of endless growth. Dewey distinguishes three emergent plateaus. The first two are the "physico-chemical activity of inanimate bodes" and the "psycho-physical," which denotes the conjunctive presence in activity of need-demand-satisfaction." ${ }^{56}$ Here is how Dewey characterizes the highest plateau:

But body-mind simply designates what actually takes place when a living body is implicated in situations of discourse, communication and participation. In the hyphenated phrase body-mind, "body" designates the continued and conserved, the registered and cumulative operation of factors continuous with the rest of nature... while "mind" designates the characters and consequences which are differential, indicative of features which emerge when "body" is engaged in a wider, more complex and interdependent situation. ${ }^{57}$

Body-minds emerge when linguistic functioning supplements bodily functioning. ${ }^{58}$

In what follows, Dewey describes the primordial act of acquiring linguistic meaning; those already familiar with Ludwig Wittgenstein's slab game ${ }^{59}$ already know the shtick: 
A requests B to bring him something, to which A points, say a flower. There is an original mechanism by which B may react to A's movement in pointing. But natively such a reaction is to the movement, not to the pointing, not to the object pointed out. But B learns that the movement is a pointing; he responds to it not in itself, but as an index of something else. His response is transferred from A's direct movement to the object to which A points. ${ }^{60}$

In this transaction, $\mathrm{A}, \mathrm{B}$, and $\mathrm{C}$ all undergo transformation as the object (e.g., a flower) begins to emerge as a common referent that allows them to coordinate their conduct together. We may think of $\mathrm{A}$ as a teacher, B as a student, and the object $\mathrm{C}$ as some subject matter. Meaning emerges in the process:

Language is made up of physical existences; sounds, or marks on paper, or a temple, statue, or loom. But these do not operate or function as mere physical things when they are media of communication. They operate in virtue of their representative capacity or meaning. ${ }^{61}$

We are at the very core of Dewey's social constructivism: “Through speech a person dramatically identifies himself with potential acts and deeds; he plays many roles, not in successive stages of life but in a contemporaneously enacted drama. Thus mind emerges." ${ }^{62}$ Minds are made when bodies acquiring meaning. Teachers contribute to the creation of body-minds by coordinating subject-matter with their students. Meaning is co-created. We make meaning together.

Linguistic interactions are reciprocally trans-forming transactions. The relation between teacher, student, and subject matter is a fine example. In Democracy and Education, Dewey declares:

Not only is social life identical with communication, but all communication . . . is educative. To be a recipient of a communication is to have an enlarged and changed experience.... Nor is the one who communicates left unaffected. Try the experiment of communicating, with fullness and accuracy, some experience to another ... and you will find your own attitude toward your experience changing. ${ }^{63}$

Because we make meaning together, teachers undergo transformation along with their students. Creative teachers enjoy such transactions because they allow them to learn and grow with their students. They are also means to the sort of immediate anoetic consummatory experiences that provide the aesthetic pleasures of teaching.

Thus far, we have concentrated on the artistic, mediating, and instrumental process of producing meaning and knowledge, but we have said little about the immediate, consummatory, and aesthetic experiences we create together. Consider the following:

Communication is uniquely instrumental and uniquely final. It is instrumental as liberating us from the otherwise overwhelming pressure 
of events and enabling us to live in a world of things that have meaning. It is final as a sharing in the objects and arts precious to a community, a sharing whereby meanings are enhanced, deepened and solidified in the sense of communion.... The great evil lies in separating instrumental and final functions. ${ }^{64}$

The great evil committed by many of Dewey's critics arises because they confuse his instrumentalism with his entire philosophy. They ignore the fact that he wrote one of the most influential works on aesthetics of the twentieth century. What he says about the creation of meaning extends to the creation of knowledge, since "if scientific discourse is instrumental in function it also is capable of becoming an enjoyed object to those concerned in it." ${ }^{65}$ We must not forget the distinction between mediating instrumentalist artistic production and immediate consummatory aesthetic enjoyment of the product. We must also remember the importance of aesthetic appreciation to successful construction every step along the way as well as the importance of artistic production to aesthetic appreciation.

We now turn to the artistic production of knowledge. Recall that the emergence of the scientific method as an extension of practical trial and error brought theory and practice together in experimentalism. The Quest for Certainty is Dewey's most extensive work on epistemology. In it, he rejects the very idea of indubitable knowledge while defending the participatory stance against that of the spectator. The work is subtitled "A Study of the Relation of Knowledge to Action." The action he has in mind is creative action. In a letter to Sidney Hook, Dewey proposed the title: The Quest for Certainty, a Study in the relations of Theory and Practice. ${ }^{6}$ What unifies theory and practice is the construction and reconstruction of meaning, knowledge, and value.

The following statement discloses the functional interdependency of theory and practice in production:

Theory separated from concrete doing and making is empty and futile; practice then becomes an immediate seizure of opportunities and enjoyments which conditions afford without the direction which theoryknowledge and ideas-has power to supply. The problem of the relation of theory and practice is not a problem of theory alone; it is that, but it is also the most practical problem of life. For it is the question of how intelligence may inform action, and how action may bear the fruit of increased insight into meaning: a clear view of the values that are worth while and of the means by which they are to be made secure in experienced objects. ${ }^{67}$

Let us further consider the importance of "making" in this passage.

The art of science has knowing (i.e., the construction of warranted assertions) as its aesthetic artifact. Dewey observes, "We know an object when we know how it is made, and we know how it is made in the degree in which we ourselves make 
it." ${ }^{68}$ In defining his terms in Logic: The Theory of Inquiry, Dewey declares: "The name objects will be reserved for subject-matter so far as it has been produced and ordered in settled form by means of inquiry; proleptically, objects are the objectives of inquiry."69 All ontology is an artifact of inquiry. Here is how Dewey sums up the argument of his Logic: "The position may be stated in the following language: All controlled inquiry and all institution of grounded assertion necessarily contains a practical factor; an activity of doing and making which reshapes antecedent existential material which sets the problem of inquiry." ${ }^{70}$ We make values in much the same way we make meaning and knowledge.

Dewey titles Chapter 10 of The Quest for Certainty "The Construction of the Good." It follows a chapter titled "The Supremacy of Method." For him, the scientific method is the supreme artistic method for making warranted assertions and the handmaiden of other arts. We must also remember that science itself is a falsifiable, contingent, and evolving social construction continuous with common sense inquiries, including indigenous methods, and is hence capable of modification by them.

In a reply to a critic who misread The Quest for Certainty, Dewey begins by reminding the reader that inquiry "is reconstructive of antecedent situations, a reconstruction in which the self as knower is changed as well as the environing conditions." ${ }^{71}$ What Dewey says next condenses his whole theory of the construction of value into a brief statement:

The function of the chapter on "The Supremacy of Method" is thus quite literally to prepare for the discussions of the next chapter, which is entitled "The Construction of Good." That is to say, precisely because I hold that experimental method as union of theory and practice, of ideas and operations directed by them, has supremacy over an antecedent situation, I also hold that one and the same method is to be used in determination of physical judgment and the value-judgments of morals. In consequence I hold that enjoyments, objects of desires as they arise, are not values, but are problematic material for construction-for creation if you will - of values. The dualism between scientific and moral knowing arose, as I point out, before the rise of the experimental method in scientific knowing. ${ }^{72}$

We must avoid the philosophic fallacy of thinking that antecedent objects of desire are values when they are only the existential materials of inquiry: "Without the intervention of thought, enjoyments are not values but problematic goods, becoming values when they re-issue in a changed form from intelligent behavior." ${ }^{\text {"3 }}$

The most complete statement of Dewey's stance occurs in The Theory of Value, to which we now turn. For him, desire is constitutive of value, much as it is constitutive of practical reasoning. ${ }^{74}$ However, the mere fact that we desire something does not make it valuable. Upon reflective inquiry many things we desire turn out not to be valuable at all. ${ }^{75}$ I still covet chocolate in spite of my high cholesterol. I should have inquired into the consequence of my desires sooner. 
Like any inquiry, value inquiry begins in a tensive problematic situation of disrupted functioning:

It follows that valuation in its connection with desire is linked to existential situations and that it differs with differences in its existential context. Since its existence depends upon the, situation, its adequacy depends upon its adaptation to the needs and demands imposed by the situation ${ }^{76}$.

Since we are participants and not spectators, our needs and the desires to which they give rise are part of the disrupted existential situation that initiates inquiry. The object of inquiry is to transform them (and the rest of the self) along with the environmental components into a single functionally coordinated situation. As with any inquiry, it involves nonexistential ideal ends-in-view that provide the guiding goal, good, or value of the inquiry.

Culturally entrenched customary rules and norms of any given culture establish moral oughts that guide practice, including moral practice. They specify what we should do; as Dewey says: "Such rules are used as criteria or 'norms' for judging the value of proposed modes of behavior." ${ }^{\prime 7}$ Many insist that some rules and norms are intrinsically good (and right) in themselves; they are never means to anything more. While Dewey agrees that we have non-instrumental intrinsic consummatory experience of the values we create, in the next moment we may use them instrumentally.

Customary values, along with rules and norms for their appraisal, are merely the results of unreflective cultural inquiry that may serve as hypotheses to be tested by intelligent inquiry and appraisal. Thus with abrupt swiftness, we are brought to description of inquiry similar to the one cited earlier:

For what is deliberation except weighing of various alternative desires (and hence end-values) in terms of the conditions that are the means of their execution, and which, as means, determine the consequences actually arrived at? There can be no control of the operation of foreseeing consequences (and hence of forming ends-in-view) save in terms of conditions that operate as the causal conditions of their attainment. The proposition in which any object adopted as an end-in-view is statable (or explicitly stated) is warranted in just the degree to which existing conditions have been surveyed and appraised in their capacity as means. ${ }^{78}$

Predictably,

The form of an attained end or consequence is always the same: that of adequate coordination. The content or involved matter of each successive result differs from that of its predecessors; for, while it is a reinstatement of a unified ongoing action, after a period of interruption through conflict and need, it is also an enactment of a new state of affairs. It has the qualities and properties appropriate to its being the consummatory resolution of a previous state of activity in which there was a peculiar need, desire, and end-in- view. ${ }^{79}$ 
In conclusion, if we unify theory with practice, we may use the same paradigm for the intelligent production of meaning, knowing, and valuing, thereby obviating the functional independencies among them.

\section{BiBLIOGRAPHY}

Aristotle. "Nichomachean Ethics." In The Basic Works of Aristotle, edited by Richard McKeon, 935-1112. New York: Random House, 1941.

Dewey, John. "Moral Theory and Practice." In John Dewey: The Early Works, edited by Jo Ann Boydston, vol. 3, 93-109. Carbondale: Southern Illinois University Press

Dewey, John. "The Present Position of Logical Theory." In John Dewey: The Early Works, edited by Jo An Boydston, vol. 3, 125-141. Carbondale: Southern Illinois University Press, 1969.

Dewey, John. "The Logic of Judgments Of Practice." In John Dewey: The Middle Works, edited by Jo An Boydston, vol. 8, 14-82. Carbondale: Southern Illinois University Press, 1979.

Dewey, John. Democracy and Education. In John Dewey: The Middle Works, edited by Jo Ann Boydston, vol. 9. Carbondale: Southern Illinois University Press, 1980.

Dewey, John. "Reconstruction in Philosophy." In John Dewey: The Middle Works, edited by Jo Ann Boydston, vol. 12. Carbondale: Southern Illinois University Press, 1982.

Dewey, John. Human Nature and Conduct. In John Dewey: The Middle Works, edited by Jo Ann Boydston, vol. 14. Carbondale: Southern Illinois University Press, 1983.

Dewey, John. Experience and Nature. In John Dewey: The Later Works, edited by Jo Ann Boydston, vol. 1. Carbondale: Southern Illinois University Press, 1981.

Dewey, John. "Body and Mind." In John Dewey: The Later Works, edited by Jo Ann Boydston vol. 3, 25-40. Carbondale: Southern Illinois University Press, 1984.

Dewey, John. The Quest for Certainty. In John Dewey: The Later Works, edited by Jo Ann Boydston, vol. 4. Carbondale: Southern Illinois University Press, 1984.

Dewey, John. "Sources of a Science Of Education." In John Dewey: The Later Works, edited by Jo Ann Boydston, vol. 5, 3-40. Carbondale: Southern Illinois University Press, 1984.

Dewey, John. "Construction and Criticism." In John Dewey: The Later Works, edited by Jo Ann Boydston, vol. 5, 127-143. Carbondale: Southern Illinois University Press, 1984.

Dewey, John. "Qualitative Thought." In John Dewey: The Later Works, edited by Jo Ann Boydston, vol. 5, 243-62. Carbondale: Southern Illinois University Press, 1984.

Dewey, John. Art as Experience. In John Dewey: The Later Works, edited by Jo Ann Boydston, vol. 10. Carbondale: Southern Illinois University Press, 1987. 
Dewey, John. "Logic: The Theory of Inquiry." In John Dewey: The Later Works, edited by Jo Ann Boydston, vol. 12. Carbondale: Southern Illinois University Press, 1986.

Dewey, John. "Experience and Education." In John Dewey: The Later Works, edited by Jo Ann Boydston, vol. 13, 1-62. Carbondale: Southern Illinois University Press, 1988.

Dewey, John. “The Theory of Valuation." In John Dewey: The Later Works, edited by Jo Ann Boydston, vol. 13, 191-251. Carbondale: Southern Illinois University Press, 1988.

Dewey, John. "Experience, Knowledge and Value: A Rejoinder." In John Dewey: The Later Works, edited by Jo Ann Boydston, vol. 14, 3-90. Carbondale: Southern Illinois University Press., 1991.

Hickman, Larry A. John Dewey's Pragmatic Technology. Bloomington: Indiana University Press, 1990.

Peters, Francis E. Greek Philosophical Terms: A Historical Lexicon. New York: New York University Press, 1967.

Quine, W. V. "Ontological relativity." In Ontological Relativity and Other Essays, 26-68. New York: Columbia University Press, 1969.

Seigfried, Charlene Haddock. Pragmatism and Feminism: Reweaving the Social Fabric. Chicago: The University Of Chicago Press, 1996.

Wittgenstein, Ludwig. Philosophical Investigations. New York: The Macmillan Company, 1953.

Waks, Leonard. "The Means-Ends Continuum and the Reconciliation of Science and Art in the Later Works of John Dewey." In Transactions of the Charles $S$. Peirce Society, XXXV, no. 3 (1999), 595-611.

\section{Notes}

1. LW 5, 127.

2. Francis E. Peters, Greek Philosophical Terms: A Historical Lexicon (New York: New York University Press, 1967), 194

3. There is another sense of theoria as simply standing back a bit within the natural world to get a better perspective. This is the act of reflection and Dewey strongly endorses it.

4. EW 3, 138.

5. See LW 12, 93.

6. MW 8, 81.

7. $\operatorname{LW} 1,28$.

8. Ibid.

9. Ibid., 29-30.

10. LW 12,18

11. Ibid., 17. See also Leonard Waks, "The Means-Ends Continuum and the Reconciliation of Science and Art in the Later Works of John Dewey," Transactions of the Charles S. Peirce Society, XXXV, no. 3 (1999), 595-611. 
12. LW 12, 111.

13. Earlier in his career Dewey used the word "tensional" to describe the disrupted situation. In many ways it is a better choice, since readers are less likely to confuse "problematic" with "problem" thereby becoming terribly confused (see LW 12, 326).

14. In a footnote found in his Logic, Dewey writes: "What I have said in Art as Experience, in chapter VII, on 'The Natural History of Form' can be carried over, mutatis mutandis, to logical forms" (LW 12, 372).

15. Ibid., 108.

16. $\operatorname{LW~1,~} 278$.

17. Ibid., 125.

18. Ibid., 268.

19. Ibid., 268-269.

20. Ibid., 269.

21. LW 5, 252.

22. LW 10, 33.

23. LW 5, 6.

24. MW 3, 100.

25. EW 3,105.

26. Aristotle, Nichomachean Ethics 1113a, 1-2.

27. LW 5, 249.

28. MW 14, 132-133

29. There is a robust pragmatist feminism that launches with Dewey's emphasis upon embodiment. See Seigfried (1996) and much work since then.

30. MW 14, 136.

31. MW 3, 98.

32. MW 14, 136.

33. MW 12, 258.

34. Ibid., 269.

35. MW 9, 269-270.

36. See U.S. Department of Education's Institute of Education Sciences (IES), the What Works Clearinghouse (WWC), created in 2002: http://ies.ed.gov/ncee/wwc/

37. LW 13, 43.

38. See Liddell-Scott-Jones Lexicon of Classical Greek online at: http://perseus.mpiwgberlin.mpg.de/cgi-bin///lexindex?lang=greek\&display=\&lookup=pra\%3Dgma.

39. See Liddell-Scott-Jones Lexicon of Classical Greek online at: http://perseus.mpiwg-berlin.mpg.de/cgi-bin///resolveform?lookup=praxis\&type=begin\&lang=greek\&searchText=\&op tions $=$ Sort + Results + Alphabetically\&.submit=Submit\&formentry $=1 \&$ display $=\&$ lang=greek .

40. Peters, Greek Philosophical Terms, 163.

41. See Liddell-Scott-Jones Lexicon of Classical Greek on Perseus: http://perseus.mpiwgberlin.mpg.de/cgi-bin///lexindex? $\mathrm{db}=$ lsj\&lang=greek\&display $=\& f e r h / l i o s=\& l o o k u p=p o /$ nos

42. MW 9, 273.

43. Larry A. Hickman, John Dewey's Pragmatic Technology (Bloomington: Indiana University Press, 1990), 108.

44. A contemplative practice is "pure" experience in the form of a dynamically unified experience free of all extraneous elements or loose ends wherein the form of the whole is present in every part. This is what Dewey calls in his aesthetics "an experience." The quality of such immediate anoetic experience can help clarify cognitive experience. It is rather like 
transcendence in naturalistic immanence. I would like to thank David Hansen for calling this possibility to my attention.

45. MW 12, 149.

46. $\operatorname{LW} 1,339$.

47. LW $4,71$.

48. LW 4, 38-39.

49. Hickman, Dewey's Pragmatic Technology, 18.

50. LW 10, 153.

51. LW 10, 53.

52. LW 3, 25.

53. LW 1, 144.

54. As with all analogies, this one flounders because antecedent events are merely materials for construction, not named things like "grapes."

55. LW 1, 34.

56. LW 1, 195-196.

57. LW 1, 217.

58. When linguistic functioning emerges "the qualities of organic action that are feelings are pains, pleasures, odors, colors, noises, tones, only potentially and proleptically. With language they are discriminated and identified" (LW, 198).

59. Ludwig Wittgenstein, Philosophical Investigations, New York: The Macmillan Company, 1953.

60. LW 1, 140. See Quine's 1969 essay on “Ontological Relativity.” Dewey gives the reader the name (flower), but in an actual situation A and B must work out the name for themselves.

61. LW 1, 52 .

62. Ibid.135. Medical models of "what works" are ill equipped to handle the intentional domain of symbolic and linguistic meaning.

63. MW 9, 8-9.

64. LW 1, 159.

65. Ibid., 160

66. 1929.01.04 (05719): John Dewey to Sidney Hook.

67. LW 4, 224-225.

68. LW $1,319$.

69. LW 12, 122.

70. Ibid., 162).

71. LW 14, 67.

72. Ibid., 66.

73. Ibid., 207.

74. LW 13, 204.

75. Ibid., 204-207.

76. Ibid., 205.

77. Ibid., 209.

78. Ibid., 213.

79. Ibid., 234.

Jim Garrison is at Virginia Polytechnic Institute and State University.

E-mail: wesley@vt.edu 
